\title{
Spatial variation of metals and phosphorus in sediments of a river influenced by urbanization
}

\author{
Variação espacial de metais e fósforo em sedimentos de rio influenciado \\ pela urbanização
}

\author{
Daniel Macedo Neto ${ }^{1}$, Sandro Froehner ${ }^{1}$ and Juan Sanez ${ }^{1}$ \\ ${ }^{1}$ Universidade Federal do Paraná, Curitiba, PR, Brazil \\ E-mails: danielmacedoneto@yahoo.com.br(DMN),froehner@ufpr.br (SF), sanez.juan@gmail.com (JS)
}

Received: May 08, 2016 - Revised: August 03, 2016 - Accepted: November 02, 2016

\begin{abstract}
The suspended sediments are a special compartment that characterizes the effects of land use in the watershed. Such compartment is able to trap organic compounds as well as metals in general. Spatial variation of concentrations can be accounted for the land use, soil composition and pollution. In this work, we aimed to assess the spatial variation of metals and phosphorus concentration presented in suspended sediments collected in a river under urban occupation. Using time-integrated suspended sediment samplers, samples were collectec in three sites covering different levels of occupation: Almirante Tamandaré (P1) and two in Curitiba city (Tingui Park -P2 and Barigui Park - P3). The sampler was settled to be $20 \mathrm{~cm}$ below the water surface and it was removed after 30 days. Twelve samples were collected to examining the following elements $\mathrm{Al}, \mathrm{As}, \mathrm{Ba}, \mathrm{Ca}, \mathrm{Cd}, \mathrm{Co}, \mathrm{Cr}, \mathrm{Cu}, \mathrm{Fe}, \mathrm{K}, \mathrm{La}, \mathrm{Mg}, \mathrm{Mn}, \mathrm{Na}, \mathrm{Nb}, \mathrm{Ni}, \mathrm{P}, \mathrm{Pb}, \mathrm{Sc}$, $\mathrm{Sn}, \mathrm{Sr}$, Th, Ti, V, Y, Zn and Zr by ICP-OES. The first site is characterized with only $5.73 \%$ of urban area; meanwhile the site P3 has the highest urban area 54.06\%. Among the twenty seven elements, nineteen showed a positive variation in concentration between collected sites, giving indication that an enrichment of metals along the river. The following elements showed positive variation: $\mathrm{P}(151.20 \%)$, $\mathrm{La}(117.98 \%), \mathrm{Cd}(93.33 \%), \mathrm{Cr}(71.43 \%), \mathrm{Na}$ (68.75\%), Ni (68.07\%), Y (66.67\%), Th (63.64\%) and Zn (56.77\%). Considering local reference values it is concluded that $\mathrm{Cd}, \mathrm{Cr}, \mathrm{Ni}, \mathrm{P}, \mathrm{Y}$ and $\mathrm{Zn}$ appear associated with urbanization increase in the basin; Co, Sc, Sn, $\mathrm{Cu}$ and $\mathrm{Mn}$ appear possibly associated with urbanization; $\mathrm{Ba}, \mathrm{La}, \mathrm{Na}, \mathrm{Pb}$ and $\mathrm{Sr}$ show inconclusive behavior in relation with urban influence ; $\mathrm{Al}, \mathrm{Fe}, \mathrm{Nb}, \mathrm{Th}, \mathrm{Ti}, \mathrm{As}, \mathrm{Ca}, \mathrm{K}, \mathrm{Mg}, \mathrm{Zr}$ and $\mathrm{Va}$ demonstrate not be associated with urbanization.
\end{abstract}

Keywords: Suspended sediments; Metals; Urban river.

\section{RESUMO}

Os sedimentos em suspensão formam compartimento ambiental especial que caracteriza os efeitos do uso do solo na bacia hidrográfica. Tal compartimento é capaz de armazenar compostos orgânicos e metais em geral, cujas variações espaciais nas concentrações podem ser associadas ao uso do solo, à composição do solo e à existência de fontes poluidoras na bacia. Aqui avaliamos a variação espacial da concentração de metais e fósforo nos sedimentos em suspensão em rio sob influência urbana. Por meio de amostradores integrados no tempo, amostras foram coletadas em três pontos com diferentes níveis de ocupação urbana: com 5,73\%, 22,30\% e com 54,06\% de urbanização. Cada amostrador foi instalado de modo a ficar $20 \mathrm{~cm}$ abaixo da superfície da água, sendo coletadas amostras a cada 30 dias em cada ponto amostral. Doze amostras foram obtidas para análise de 27 elementos químicos. Dos 27 elementos selecionados para análise, 19 apresentaram taxas de variação de concentração positivas, indicando enriquecimento ao longo do trecho de rio amostrado. As maiores taxas de variação positivas foram obtidas para P (151,20\%), La (117,98\%), Cd (93,33\%), Cr (71,43\%), Na (68,75\%), $\mathrm{Ni}(68,07 \%)$, Y (66,67\%), Th (63,64\%) e Zn (56,77\%). Considerando a comparação com valores de referência locais conclui-se que $\mathrm{Cd}, \mathrm{Cr}$, Ni, P, Y e Zn aparecem associados ao aumento de urbanização na bacia; Co, Sc, Sn, Cu e Mn aparecem possivelmente associados à urbanização; $\mathrm{Ba}, \mathrm{La}, \mathrm{Na}, \mathrm{Pb}$ e Sr demonstram comportamento inconclusivo em relação à influência urbana; e Al, Fe, Nb, Th, Ti, As, $\mathrm{Ca}, \mathrm{K}, \mathrm{Mg}$, Va e Zr demonstram não estar associados ao aumento de urbanização.

Palavras-chave: Sedimentos em suspensão; Metais; Rio urbano. 


\section{INTRODUCTION}

Sediments, in general, have the capacity to adsorb and bind metals, organic compounds and nutrients (MIGUEL et al., 2005; TAYLOR; OWENS, 2009). Thus, sediments can be considered as the final destination of some pollutants as well as sources of pollution that can interfere in the biota (BURTON JUNIOR, 2002). Metals, in general, in suspended sediments are often used as indicative of land use changes, for instance increase of urbanization level (HOROWITZ; ELRICK; SMITH, 2008).

Recently, it has been demonstrated that the presence and distribution of metals in suspended sediments can be complex and does not follow a constant variation to associate with land use and occupation. Some authors found no significant variation in metals concentrations (ZGHEIB; MOILLERON; CHEBBO, 2011; GALLO et al., 2013), but others found significant variation (VALTANEN; SILLANPAA; SETALA, 2014; MCKEE; GILBREATH, 2015). The main potential sources of metals in sediments, especially in urbanized areas, are paved and unpaved streets, residential and industrial areas, also sewage discharges (SILVA; SIQUEIRA; LEANDRO, 2015; FRANZ et al., 2014; MIGUEL et al., 2005).

However, many metals and inorganic compounds are natural present in soil constitution of the watershed, thus sometimes is not an easy task to distinguish between polluted and unpolluted condition based on metal distribution (BURTON JUNIOR, 2002).

Chemical elements (metals and semi-metals) such as As, $\mathrm{Cd}, \mathrm{Co}, \mathrm{Cr}, \mathrm{Cu}, \mathrm{Mn}, \mathrm{Ni}, \mathrm{Pb}$ and $\mathrm{Zn}$ have been considered as a fingerprint to trace pollution in urban areas (GOMES et al., 2009; POLETO; MERTEN; MINELLA, 2009; RIVARO et al., 2011; MCKEE; GILBREATH, 2015). Despite the discussion about iron, some authors also include this metal as tracer of pollution (POLETO; MERTEN; MINELLA, 2009; MCKEE; GILBREATH, 2015; SILVA; SIQUEIRA; LEANDRO, 2015), even been one of the most abundant on Earth as well $\mathrm{Al}, \mathrm{Ca}, \mathrm{K}, \mathrm{Mg}$, Si and Ti.

Researchers had considered other groups of metals, although with lower abundance. Those metals are $\mathrm{Ba}, \mathrm{Na}, \mathrm{P}, \mathrm{V}$ and $\mathrm{Zr}$. The natural occurrence of these metals is from 100 to 1,000 ppm. According to Mineropar (2005) La, Nb, Sc, Sn, Sr, Th and Y also are found, but in lower concentrations (lower than $100 \mathrm{ppm}$ ).

The aim of this work was to evaluate the spatial variation of metals and phosphorus in suspended sediments of a river influenced by urbanization.

\section{METHODS AND MATERIALS}

\section{Study area and sampling sites}

The study area comprehended the upper part of Barigui River watershed (25'13'24" and 25 $38^{\circ} 23^{\prime \prime}$ 'South; $49^{\circ} 15^{\prime} 00^{\prime \prime}$ and $49^{\circ} 22^{\prime} 29^{\prime \prime}$ West). This part has $131 \mathrm{~km}^{2}$ of drainage area. The annual mean precipitation varied from 1,400 to 1,600 mm (IAPAR, 2013), well distributed along the year. The mean value of river flow, considering the last 30 years, was $5.64 \mathrm{~m}^{3} \mathrm{~s}^{-1}$, being the maximum 111.0 in January 1995, while the minimum was $0.25 \mathrm{~m}^{3} \mathrm{~s}^{-1}$ in 1982 .
In this work, it was selected three sites for sampling in the watershed. The monitoring plan considered suspended sediments sampling every month. (Table 1 and Figure 1).

The discharge of solids into river were 10 to 20 ton day ${ }^{-1}$ for P1, 20 to 60 ton day ${ }^{-1}$ for P2 and 10 to 50 ton day ${ }^{-1}$ for P3. It is highlighted that site $\mathrm{P} 3$ retain most of solids due the lake designed for such purpose, in contrast to other sites (CHELLA; FERNANDES; FERMIANO, 2005).

\section{Land use in the study area}

The land use was obtained examining the geographic information system (GIS) provided by Instituto das Águas do Parana. This GIS was designed in scale 1:20,000 based on aerophotometric data in 1:30,000 scale. The rural areas on GIS was achieved by restitution of aerophotometric datas for rural areas in lower scale $(1: 10,000)$ and thematic mapping $(1: 20,000)$ (SUDERHSA, 2000).

Unfortunately, information about land use was quite old for this study, thus it was considered the population growth and urbanization level of the watershed (IPPUC, 2012; IPARDES, 2016).

According to the analysis of GIS and recent datas about population growth and urbanization index, it was detected nine classes of land use: urban, industrial, mining, grazing, reforesting, agriculture, soil without coverage and others (Figure 1).

\section{Sampling procedure}

In order to obtain the suspended sediments, it was used a time-integrated sampler of fluvial sediments (GRUSZOWSKI et al., 2003; FOX, 2009; WALLING et al., 2006; FOX; PAPANICOLAOU, 2007; FOX; MARTIN, 2014).

The sampler consists in a PVC tube with narrow entrance and narrow output $(4 \mathrm{~mm})$. The body of sampler has $100 \mathrm{~mm}$ as diameter and $100 \mathrm{~cm}$ length. Briefly, the reduction of speed flow allows the sedimentation of suspended particles inside the tube.

The samplers were settled approximately $20 \mathrm{~cm}$ below the water surface and $1.5 \mathrm{~m}$ from the river bank, according the procedures described in the literature (MCDONALD; LAMOUREUX; WARBURTON, 2010; PHILLIPS; RUSSELL;

Table 1. Sampling sites and their characteristics.

\begin{tabular}{lcccc}
\hline \multirow{2}{*}{ Site } & $\begin{array}{c}\text { Drainage } \\
\text { area }\left(\mathbf{k m}^{2}\right)\end{array}$ & \multicolumn{2}{c}{$\begin{array}{c}\text { Geographic } \\
\text { coordinates }\end{array}$} & Elevation* \\
& Latitude & Longitude & \\
\hline $\begin{array}{l}\text { P1 - } \\
\begin{array}{l}\text { Almirante } \\
\text { Tamandaré }\end{array}\end{array}$ & 44.00 & $25^{\circ} 18^{\prime} 46^{\prime \prime}$ & $49^{\circ} 17^{\prime} 44^{\prime \prime}$ & 944 \\
\hline $\begin{array}{l}\text { P2 - } \\
\text { Parque } \\
\text { Tinguí }\end{array}$ & 87.70 & $25^{\circ} 23^{\prime} 21^{\prime \prime}$ & $49^{\circ} 18^{\prime} 18^{\prime \prime}$ & 905 \\
\hline $\begin{array}{l}\text { P3 - } \\
\text { Parque } \\
\text { Barigui }\end{array}$ & 131.70 & $25^{\circ} 25^{\prime} 34^{\prime \prime}$ & $49^{\circ} 18^{\prime} 24^{\prime \prime}$ & 897 \\
\hline * Above the sea mean level. & & & \\
\hline
\end{tabular}


WALLING, 2000). The width of river and the respective sites were: P1 - $9 \mathrm{~m}, \mathrm{P} 2-8 \mathrm{~m}$ and P3 - $25 \mathrm{~m}$.

The sampler was fixed in a steel support that was then fixed in the riverbed. The sampler were left during 30 days and collected monthly. Before analysis, samples were kept at $4{ }^{\circ} \mathrm{C}$.

\section{Determination of metals and phosphorus concentrations in samples}

The samples containing the sediments were filtered $(14 \mu \mathrm{m})$ under vacuum and then, dried at $40{ }^{\circ} \mathrm{C}$ for $24 \mathrm{~h}$. Before further analysis, samples were crushed and pulverized for chemical analysis. For granulometric composition it was considered the fine fraction $(<63 \mu \mathrm{m})$ (POLETO et al., 2009; CARTER et al., 2003; DAVIS; FOX, 2009).

The granulometric composition was obtained by a laser granulometer. While the quantification of metals and $\mathrm{P}$ was achieved by inductively coupled plasma optical emission spectrometry (ICP-OES). The following elements were analyzed: Al, As, Ba, $\mathrm{Ca}, \mathrm{Cd}, \mathrm{Co}, \mathrm{Cr}, \mathrm{Cu}, \mathrm{Fe}, \mathrm{K}, \mathrm{La}, \mathrm{Mg}, \mathrm{Mn}, \mathrm{Na}, \mathrm{Nb}, \mathrm{Ni}, \mathrm{P}, \mathrm{Pb}, \mathrm{Sc}, \mathrm{Sn}$, Sr, Th, Ti, V, Y, Zn and Zr.

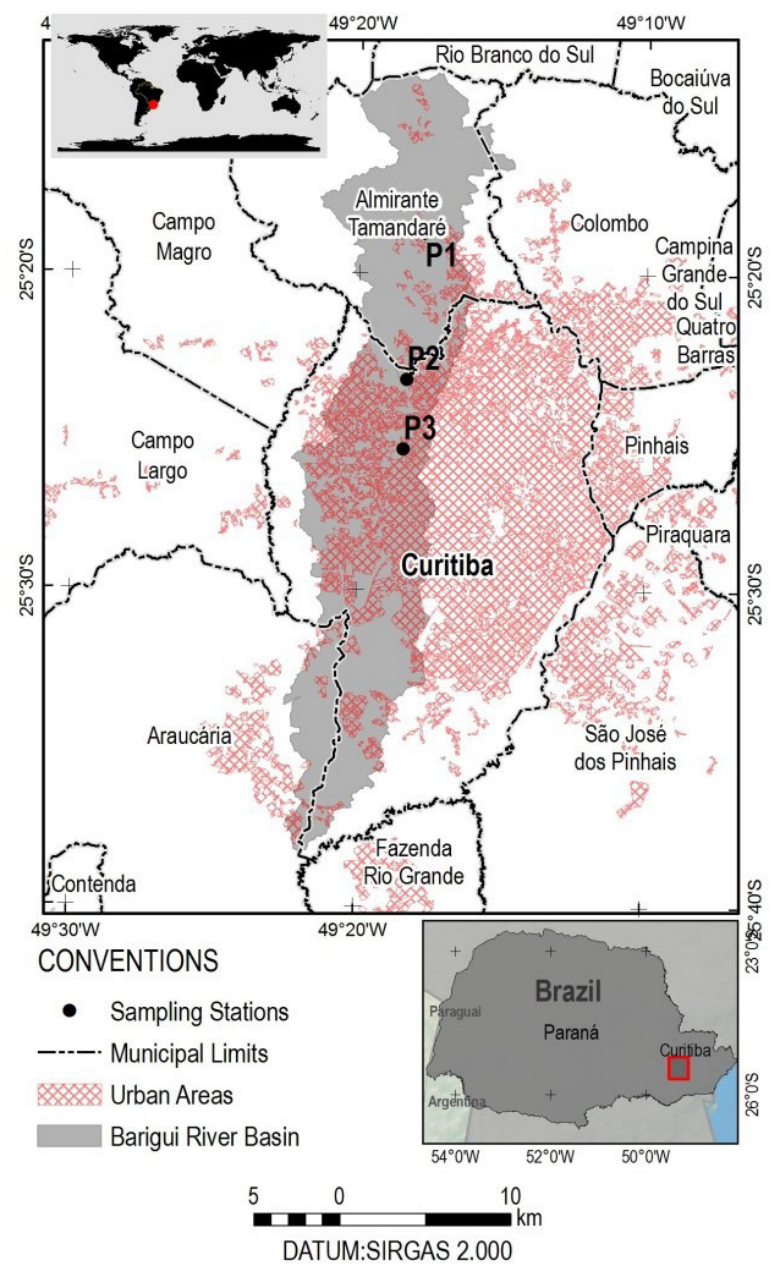

Figure 1. Study area, sampling sites and urban land use.

\section{Statistical analysis}

The principal component analysis (PCA) was used to explain the variance-covariance structure of a set of metals and $\mathrm{P}$ through linear combinations.

\section{RESULTS AND DISCUSSION}

\section{Land use in the study area}

The site P1 comprehend $5.73 \%$ of urbanized areas. In this area, even is classified as urban, still exists natural vegetation (86.19\%), however, most of them are represented by grazing and vegetation for commercial purpose. In this segment, it is found the largest extension of Barigui River inside the metropolitan area of Curitiba. The P2 site represents $22.30 \%$ of land occupied by urbanized area. It is highlighted that natural vegetation corresponds to $57.07 \%$. It can be observed many inputs and discharges from Almirante Tamandaré and some neighborhoods of Curitiba in this segment. While P3 contains $54.05 \%$ of urbanized area. In this area, $41.15 \%$ is covered by natural vegetation and fields (Table 2).

It is interesting that the urbanization level increase from $\mathrm{P} 1$ to $\mathrm{P} 3$. The P2 site is the intermediate in despite of urbanization.

\section{Concentration of phosphorus and metals}

In order to better understand the great number of metals analyzed in suspended sediments, the metals and $\mathrm{P}$ were grouped according the abundance of each element, thus in Table 3 is showed the groups formed and level of concentration found.

Most of elements were found as low concentration range (100 to $1,000 \mathrm{mg} \mathrm{kg}^{-1}$ ) (Table 4). Among these metals, it was found those elements associated with urban and industrial activities. Those metals are typical for industrial and urban areas. Those elements are As, Cd, Co, Cr, Cu, Fe, Mn, Ni, Pb and $\mathrm{Zn}$ (GOMES et al., 2009; POLETO; MERTEN; MINELLA, 2009;

Table 2. Percentages of land use in the three studied segments.

\begin{tabular}{|c|c|c|c|c|c|c|}
\hline \multirow{3}{*}{$\begin{array}{c}\text { Classes of } \\
\text { soil }\end{array}$} & \multicolumn{6}{|c|}{$\begin{array}{l}\text { Watershed segments used in this study and } \\
\text { the sampling sites }\end{array}$} \\
\hline & \multicolumn{2}{|c|}{ P1 } & \multicolumn{2}{|c|}{ P2 } & \multicolumn{2}{|c|}{ P3 } \\
\hline & (ha) & $\%$ & (ha) & $\%$ & (ha) & $\%$ \\
\hline Urban & 336.5 & 5.73 & 1045.6 & 22.30 & $1,357.0$ & 54.05 \\
\hline Industrial & 57.7 & 0.98 & 54.3 & 1.16 & 19.7 & 0.79 \\
\hline Mining & 25.8 & 0.44 & 0.00 & 0.00 & 0.00 & 0.00 \\
\hline Grazing & $1,406.4$ & 23.93 & $1,120.7$ & 23.90 & 377.7 & 15.04 \\
\hline Agriculture & 340.8 & 5.80 & 496.9 & 10.60 & 23.6 & 0.94 \\
\hline $\begin{array}{c}\text { Natural } \\
\text { vegetation }\end{array}$ & $2,302.4$ & 39.17 & $1,555.3$ & 33.17 & 655.5 & 26.11 \\
\hline Reforastation & $1,357.4$ & 23.09 & 340.9 & 7.27 & 26.3 & 1.05 \\
\hline $\begin{array}{l}\text { Exposed soil } \\
\text { and residencial } \\
\text { sub-division }\end{array}$ & 9.1 & 0.16 & 29.7 & 0.64 & 25.5 & 1.02 \\
\hline Other & 41.4 & 0.70 & 44.6 & 0.95 & 25.2 & 1.01 \\
\hline Total & $5,877.7$ & 100 & $4,688.4$ & 100 & $2,510.8$ & 100 \\
\hline
\end{tabular}


RIVARO et al., 2011; MCKEE; GILBREATH, 2015). Among this group, $\mathrm{Mn}\left(890.64 \pm 163,69 \mathrm{mg} \mathrm{kg}^{-1}\right), \mathrm{Zn}\left(179.79 \pm 46,24 \mathrm{mg} \mathrm{kg}^{-1}\right)$ and $\mathrm{Fe}\left(59.050 \pm 3.650 \mathrm{mg} \mathrm{kg}^{-1}\right)$ presented the highest concentration. The group formed with high concentration presented the following order of concentration $\mathrm{Al}>\mathrm{Fe}>\mathrm{Ca}>\mathrm{Mg}>\mathrm{K}>\mathrm{Ti}>\mathrm{P}>\mathrm{Na}$. While the group classified as low concentration presented the distribution $\mathrm{Mn}>\mathrm{Ba}>\mathrm{Zn}>\mathrm{V}>\mathrm{Zr}$. Trace elements has $\mathrm{Cr}$ in lower concentration and $\mathrm{Cd}$ in higher concentration, the sequence is $\mathrm{Cr}>\mathrm{Cu}>\mathrm{La}>\mathrm{Sr}>$ $\mathrm{Ni}>\mathrm{Y}>\mathrm{Pb}>\mathrm{Co}>\mathrm{Sc}>\mathrm{Nb}>\mathrm{Th}>\mathrm{Sn}>\mathrm{As}>\mathrm{Cd}$ (Table 4).

\section{Metal concentration and land use}

Of 27 metals examined, 19 presented positive variability between sites P1 and P3 (Figure 2). This numbers can be resulted from land use as urbanization process (Table 2). In contrast,

Table 3. Groups of metals and P according the concentration.

\begin{tabular}{|c|c|c|}
\hline Classification & $\begin{array}{l}\text { Concentration } \\
\text { range }\left(\mathrm{mg} \mathrm{kg}^{-1}\right)\end{array}$ & $\begin{array}{l}\text { Chemical } \\
\text { elements }\end{array}$ \\
\hline Ultra trace & $<1$ & Not detected \\
\hline Trace & $1-100$ & $\begin{array}{l}\text { As, Cd, Co, Cr, Cu, } \\
\text { La, Nb, Ni, Pb, Sc, } \\
\text { Sn, Sr, Th, Y }\end{array}$ \\
\hline Low concentrated & $100-1,000$ & $\mathrm{Ba}, \mathrm{Mn}, \mathrm{V}, \mathrm{Zn}, \mathrm{Zr}$ \\
\hline High concentrated & $>1,000$ & $\begin{array}{c}\mathrm{Al}, \mathrm{Ca}, \mathrm{Fe}, \mathrm{K}, \mathrm{Mg} \\
\mathrm{Na}, \mathrm{P}, \mathrm{Ti}\end{array}$ \\
\hline
\end{tabular}

As, $\mathrm{Ca}, \mathrm{Cu}, \mathrm{K}, \mathrm{Mg}, \mathrm{Mn}, \mathrm{V}$ and $\mathrm{Zr}$ showed negative variability. A substantial and negative variation was found for $\mathrm{Ca}$ and $\mathrm{Mg}$, $66.11 \%$ and $56.19 \%$ respectively.

Highest variation was found for $\mathrm{P}(151.20 \%), \mathrm{La}(117.98 \%)$, Cd (93.33\%), Cr (71.43\%), Na (68.75\%), Ni (68.07\%), Y (66.67\%), $\mathrm{Th}(63.64 \%)$ and $\mathrm{Zn}(56.77 \%)$. According to literature, the occurrence of metals such as $\mathrm{Cd}, \mathrm{Cr}, \mathrm{Ni}$ and $\mathrm{Zn}$ is not a surprise. The literature suggests a strong correlation between these metals and urban areas (GOMES et al., 2009; POLETO; MERTEN; MINELLA, 2009; RIVARO et al., 2011; MCKEE; GILBREATH, 2015).

The principal component analysis (PCA) showed that the factor 1 explains $61.20 \%$ and factor 2 explains $15.58 \%$, therefore $76.78 \%$ of data can be explained (Figure 3). It was observed that factor 1 has a positive correlation with $\mathrm{Ca}, \mathrm{K}, \mathrm{Mg}, \mathrm{Zr}$ and a

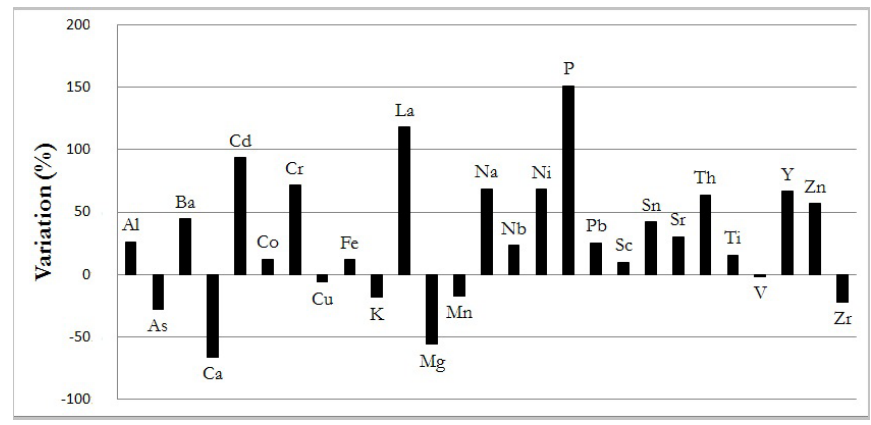

Figure 2. Percentual variability of metals and phosphorus from P1 to P3.

Table 4. Mean concentrations of metals and phosphorus found in suspend sediments.

\begin{tabular}{|c|c|c|c|c|}
\hline \multirow[b]{2}{*}{ Metalsand P } & \multicolumn{4}{|c|}{ Mean values \pm Standard deviation $\left(\mathrm{mg} \mathrm{kg}^{-1}\right)$} \\
\hline & Mean values & $\begin{array}{c}\text { Almirante Tamandaré } \\
\text { (P1) }\end{array}$ & $\begin{array}{c}\text { Tinguí Park } \\
\text { (P2) }\end{array}$ & $\begin{array}{l}\text { Barigui Park } \\
\text { (P3) }\end{array}$ \\
\hline $\mathrm{Al}$ & $102,550 \pm 11,459$ & $86,800 \pm 2,473$ & $108,050 \pm 4,665$ & $109,383 \pm 6,784$ \\
\hline As & $6.31 \pm 1.18$ & $7.75 \pm 0.50$ & $5.75 \pm 0.50$ & $5.60 \pm 0.89$ \\
\hline $\mathrm{Ba}$ & $629.21 \pm 98.48$ & $484.00 \pm 17.57$ & $668.75 \pm 23.68$ & $699.67 \pm 24.83$ \\
\hline $\mathrm{Ca}$ & $28,864 \pm 14,429$ & $49,825 \pm 2,430$ & $25,875 \pm 1,802$ & $16,883 \pm 2,228$ \\
\hline $\mathrm{Cd}$ & $1.06 \pm 0.38$ & $0.75 \pm 0.06$ & $0.78 \pm 0.05$ & $1.45 \pm 0.20$ \\
\hline $\mathrm{Co}$ & $23.14 \pm 1.35$ & $21.25 \pm 0.50$ & $24.00 \pm 0.82$ & $23.83 \pm 0.41$ \\
\hline $\mathrm{Cr}$ & $89.79 \pm 20.06$ & $59.50 \pm 3.11$ & $101.75 \pm 2.36$ & $102.00 \pm 3.16$ \\
\hline $\mathrm{Cu}$ & $84.71 \pm 8.45$ & $87.75 \pm 15.65$ & $85.25 \pm 2.06$ & $82.33 \pm 4.68$ \\
\hline $\mathrm{Fe}$ & $59,050 \pm 3,650$ & $54,500 \pm 770$ & $60,775 \pm 3,026$ & $60,933 \pm 2,367$ \\
\hline K & $15,671 \pm 1,844$ & $16,850 \pm 655.74$ & $17,350 \pm 574.46$ & $13,766 \pm 821.38$ \\
\hline $\mathrm{La}$ & $64.36 \pm 20.09$ & $38.00 \pm 1.41$ & $63.00 \pm 3.74$ & $82.83 \pm 8.54$ \\
\hline $\mathrm{Mg}$ & $20,078 \pm 7,509$ & $30,625 \pm 1,609$ & $19,525 \pm 846.07$ & $13,416 \pm 1,470$ \\
\hline $\mathrm{Mn}$ & $890.64 \pm 163.69$ & $1,048 \pm 110.47$ & $766.75 \pm 49.73$ & $868.00 \pm 167.43$ \\
\hline $\mathrm{Nb}$ & $11.21 \pm 1.19$ & $10.00 \pm 0.00$ & $10.75 \pm 0.96$ & $12.33 \pm 0.52$ \\
\hline $\mathrm{Ni}$ & $45.07 \pm 10.20$ & $29.75 \pm 1.26$ & $53.00 \pm 1.15$ & $50.00 \pm 1.26$ \\
\hline $\mathrm{P}$ & $1,718 \pm 642.98$ & $937.50 \pm 18.93$ & $1,545 \pm 98.15$ & $2,355 \pm 265.91$ \\
\hline $\mathrm{Pb}$ & $35.07 \pm 4.14$ & $31.25 \pm 1.50$ & $32.75 \pm 0.96$ & $39.17 \pm 2.56$ \\
\hline $\mathrm{Sc}$ & $21.29 \pm 1.20$ & $19.75 \pm 0.50$ & $22.25 \pm 0.50$ & $21.67 \pm 0.82$ \\
\hline $\mathrm{Sn}$ & $6.43 \pm 2.85$ & $5.75 \pm 2.06$ & $4.50 \pm 0.58$ & $8.17 \pm 3.37$ \\
\hline $\mathrm{Sr}$ & $57.43 \pm 9.56$ & $51.50 \pm 2.65$ & $49.00 \pm 1.83$ & $67.00 \pm 6.03$ \\
\hline Th & $7.29 \pm 2.46$ & $5.50 \pm 1.73$ & $6.50 \pm 1.73$ & $9.00 \pm 2.37$ \\
\hline $\mathrm{Ti}$ & $5,271 \pm 458.14$ & $4,900 \pm 182.57$ & $5,075 \pm 403.11$ & $5,650 \pm 339.12$ \\
\hline $\mathrm{V}$ & $126.64 \pm 5.47$ & $127.00 \pm 3.16$ & $129.25 \pm 8.46$ & $124.67 \pm 4.32$ \\
\hline $\mathrm{Y}$ & $38.50 \pm 8.19$ & $27.00 \pm 0.00$ & $40.25 \pm 2.22$ & $45.00 \pm 3.52$ \\
\hline $\mathrm{Zn}$ & $179.79 \pm 46.24$ & $142.25 \pm 29.50$ & $152.50 \pm 9.95$ & $223.00 \pm 31.82$ \\
\hline $\mathrm{Zr}$ & $118.29 \pm 14.97$ & $140.50 \pm 3.87$ & $109.25 \pm 2.87$ & $109.50 \pm 3.99$ \\
\hline
\end{tabular}


negative correlation was found with $\mathrm{Al}, \mathrm{Ba}, \mathrm{Cd}, \mathrm{Co}, \mathrm{Cr}, \mathrm{Fe}, \mathrm{La}$, $\mathrm{Na}, \mathrm{Nb}, \mathrm{Ni}, \mathrm{P}, \mathrm{Pb}, \mathrm{Sc}, \mathrm{Sr}, \mathrm{Ti}, \mathrm{Y}$ and $\mathrm{Zn}$. The factor 2 did not show any correlation, neither positive nor negative (Figure 3 ).

The factor 1 has a strong and positive correlation with $\mathrm{Ca}, \mathrm{K}, \mathrm{Mg}$ and $\mathrm{Zr}$, such metals were grouped in the right side of plot. In fact, those metals showed decrease in concentration

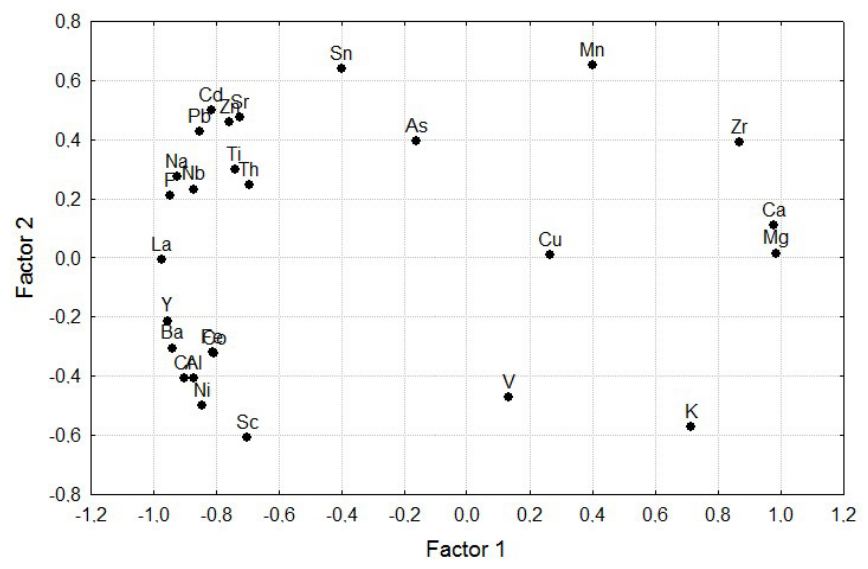

Figure 3. Principal component analysis for metals and phosphorus. pattern from P1 to P3. Lowest level of these metals are associated with increase of urbanization. Such behavior of $\mathrm{Ca}$ and $\mathrm{Mg}$ was already demonstrated by Mineropar (2001). In contrast, component 1 presented a negative correlation with $\mathrm{Al}, \mathrm{Ba}, \mathrm{Cd}, \mathrm{Co}, \mathrm{Cr}, \mathrm{Fe}$, $\mathrm{La}, \mathrm{Na}, \mathrm{Nb}, \mathrm{Ni}, \mathrm{P}, \mathrm{Pb}, \mathrm{Sc}, \mathrm{Sr}, \mathrm{Ti}, \mathrm{Y}$ and Zn. Those metals are concentrated in the left side of Figure 3. However, in the figure Sn and Th showed positive variation. Most of results found here agree with soil composition determined by Mineropar (2001), thus represent the contribution of soil by erosion, for instance. The elements $\mathrm{Al}, \mathrm{Ba}, \mathrm{La}, \mathrm{Na}, \mathrm{Ni}$ and $\mathrm{Ti}$ did not completely agree with soil composition.

The metals As, $\mathrm{Mn}, \mathrm{Cu}$ and $\mathrm{V}$ are in the middle part of Figure 3.

\section{Concentration of metals versus background values}

The establishment of values that can be used as reference is still under debate (BURTON JUNIOR, 2002). Most of times the comparison are made using international values, although those values do not represent the similar geologic composition of soil, thus misinterpretation is possible.

Table 5. Concentration of metal in suspended sediments and values adopted as background reference for level of pollution.

\begin{tabular}{|c|c|c|c|c|c|c|c|c|c|}
\hline \multirow[t]{2}{*}{ Metal } & \multicolumn{4}{|c|}{$\begin{array}{l}\text { Values in suspended } \\
\text { sediments }\left(\mathrm{mg} \mathrm{kg}^{-1}\right)\end{array}$} & \multicolumn{3}{|c|}{$\begin{array}{l}\text { Reference values according } \\
\left.\text { MINEROPAR (2005) (mg kg } \text { (m) }^{-1}\right)\end{array}$} & \multicolumn{2}{|c|}{$\begin{array}{c}\text { Reference values according } \\
\text { CONAMA 454/2012 } \\
\text { (BRASIL, 2012) }\left(\mathrm{mg} \mathrm{kg}^{-1}\right)\end{array}$} \\
\hline & $\begin{array}{l}\text { Mean } \\
\text { values }\end{array}$ & P1 & P2 & P3 & $\begin{array}{c}\text { First } \\
\text { Plateau }\end{array}$ & $\begin{array}{c}\text { Urban } \\
\text { areas }\end{array}$ & $\begin{array}{c}\text { Parana } \\
\text { State }\end{array}$ & Level 1 & Level 2 \\
\hline $\mathrm{Al}$ & 102,550 & 86,800 & 108,050 & 109,383 & 132,500 & 125,981 & 123,181 & - & - \\
\hline As & 6.31 & 7.75 & 5.75 & 5.60 & 10.47 & 9.4 & 7.25 & 5.9 & 17 \\
\hline $\mathrm{Ba}$ & 629.21 & 484.00 & 668.75 & 699.67 & 329.1 & 253.52 & 170.84 & - & - \\
\hline $\mathrm{Ca}$ & 28,864 & 49,825 & 25,875 & 16,883 & 781 & 852 & 929 & - & - \\
\hline $\mathrm{Cd}$ & 1.06 & 0.75 & 0.78 & 1.45 & 0.12 & 0.16271 & 0.8174 & 0.6 & 3.5 \\
\hline $\mathrm{Co}$ & 23.14 & 21.25 & 24.00 & 23.83 & 7.51 & 17.29 & 23.84 & - & - \\
\hline $\mathrm{Cr}$ & 89.79 & 59.50 & 101.75 & 102.00 & 85.93 & 90.44 & 105.42 & 37.3 & 90 \\
\hline $\mathrm{Cu}$ & 84.71 & 87.75 & 85.25 & 82.33 & 39.47 & 103.8 & 141.72 & 35.7 & 197 \\
\hline $\mathrm{Fe}$ & 59,050 & 54,500 & 60,775 & 60,933 & 59,150 & 84,560 & 105,266 & - & - \\
\hline K & 15,671 & 16,850 & 17,350 & 13,767 & 10,707 & 8,217 & 3,653 & - & - \\
\hline $\mathrm{La}$ & 64.36 & 38.00 & 63.00 & 82.83 & 46.3 & 42.06 & 37.95 & - & - \\
\hline $\mathrm{Mg}$ & 20,079 & 30,625 & 19,525 & 13,417 & 3,120 & 3,060 & 2,352 & - & - \\
\hline $\mathrm{Mn}$ & 891 & 1,049 & 767 & 868 & 313.24 & 560.87 & 737 & - & - \\
\hline $\mathrm{Na}$ & 1,093 & 800 & 1,000 & 1,350 & 1,110 & 666 & 445 & - & - \\
\hline $\mathrm{Nb}$ & 11.21 & 10.00 & 10.75 & 12.33 & 22.73 & 25.64 & 28.16 & - & - \\
\hline $\mathrm{Ni}$ & 45.07 & 29.75 & 53.00 & 50.00 & 25.44 & 30.47 & 34.16 & 18 & 35.9 \\
\hline $\mathrm{P}$ & 1.719 & 938 & 1.545 & 2.355 & 428,95 & 489,71 & 628 & \multicolumn{2}{|c|}{$2,000^{*}$} \\
\hline $\mathrm{Pb}$ & 35.07 & 31.25 & 32.75 & 39.17 & 28.1 & 26.14 & 23.21 & 35 & 91.3 \\
\hline $\mathrm{Sc}$ & 21.29 & 19.75 & 22.25 & 21.67 & 18.32 & 26.74 & 31.04 & - & - \\
\hline Sn & 6.43 & 5.75 & 4.50 & 8.17 & 3.75 & 3.52 & 3.38 & - & - \\
\hline $\mathrm{Sr}$ & 57.43 & 51.50 & 49.00 & 67.00 & 74.55 & 52.27 & 36.95 & - & - \\
\hline Th & 7.29 & 5.50 & 6.50 & 9.00 & 17.93 & 15.6 & 13.3 & - & - \\
\hline $\mathrm{Ti}$ & 5,271 & 4,900 & 5,075 & 5,650 & 7,501 & 11,969 & 15,726 & - & - \\
\hline $\mathrm{V}$ & 126.64 & 127.00 & 129.25 & 124.67 & 123.34 & 259.42 & 370.37 & - & - \\
\hline $\mathrm{Y}$ & 38.50 & 27.00 & 40.25 & 45.00 & 23.96 & 28.07 & 27.64 & - & - \\
\hline $\mathrm{Zn}$ & 179.79 & 142.25 & 152.50 & 223.00 & 54.31 & 66.63 & 75.26 & 123 & 315 \\
\hline $\mathrm{Zr}$ & 118.29 & 140.50 & 109.25 & 109.50 & 507.43 & 481.21 & 455.67 & - & - \\
\hline
\end{tabular}


In this work, it was used reference values (RV) by Mineropar (2005) obtained from First Plateau of Paraná and some urban area. To help in the discussion and interpretation of results, the mean values of each metal (elements) was presented in Table 5, nevertheless the comparisons was made only with reference values (RV) obtained from First Plateau of Parana. In addition, the metals $\mathrm{As}, \mathrm{Cd}, \mathrm{Pb}, \mathrm{Cu}, \mathrm{Cr}, \mathrm{Ni}, \mathrm{Zn}$ and phosphorus were compared with values for levels 1 and 2 proposed by CONAMA $n^{\circ} 454 / 2012$ (level 1 - level with minimum possibility to present an unwanted effect on biota; level 2 - level with high possibility to present unwanted side effects on biota) (BRASIL, 2012). The mean concentration of each side (P1, P2 and P3), as well the background values are presented in Table 5 .

The concentration of $\mathrm{Al}, \mathrm{Nb}, \mathrm{Th}, \mathrm{Ti}$ and $\mathrm{Zr}$ were below the values adopted as reference in all samples and sites. The concentration of Th was interesting, assuming that this metal is not abundant in this area, but it was observed a positive variability from P1 to P3, and however the values were lower than the reference value.

A different behavior was observed for $\mathrm{As}, \mathrm{Ca}, \mathrm{Cu}, \mathrm{K}, \mathrm{Mg}$, $\mathrm{Mn}$ and $\mathrm{V}$. The concentration of these metals has decreased with increase of urbanization level. For this group of metals, only As presented higher concentration than the maximum concentration recommended by CONAMA n ${ }^{\circ}$ 454/2012 (BRASIL, 2012). Higher values of As was not surprise, considering the natural presence of As in this area according to Mineropar (2005).

However, $\mathrm{Mn}, \mathrm{Cu}$ and $\mathrm{V}$ were higher than values established as normal (background). Interesting that $\mathrm{Cu}$ was higher, even than value established as safe for biota. The values of $\mathrm{Ca}$ and $\mathrm{Mg}$ showed high concentration, above typical values considered as typical for First Parana Plateau, although there is no significant impact on biota. The same behavior was observed for $\mathrm{K}$, moreover, in lower level of concentration than $\mathrm{Ca}$ and $\mathrm{Mg}$.

One group, composed by Ba, Co, Pb, Sc, Sn and Sr, presented positive variability. This variability was up to $50 \%$ from $\mathrm{P} 1$ to $\mathrm{P} 3$. In this group, it is important to highlight that $\mathrm{Ba}, \mathrm{Co}, \mathrm{Pb}$ and $\mathrm{Sn}$ exceeded the value adopted as reference. In addition, $\mathrm{Pb}$ exceeded the value for level 1 of CONAMA 454/2012 (BRASIL, 2012).

In the same way, the metal Sc presented values quite higher than reference for this metal. In contrast, Sr exceeded the reference value in P3. The geological occurrence of $\mathrm{Sc}$ in the study area is higher than other areas, including urban, thus its presence could be natural and not from anthropic source.

Finally, the group of metals with positive variability $(>50 \%)$ such as $\mathrm{Cd}, \mathrm{Cr}, \mathrm{La}, \mathrm{Na}, \mathrm{Ni}, \mathrm{P}, \mathrm{Y}$ and $\mathrm{Zn}$ showed concentration above the reference value, except for La in site P1. Most of metal showed concentration above the level 1 and 2 recommended by CONAMA. This observation could be an alert considering $\mathrm{Cr}$ and $\mathrm{Ni}$ as toxic even in lower concentrations.

Kuusisto-Hjort and Hjort (2013) observed the enrichment of $\mathrm{Cd}, \mathrm{Pb}, \mathrm{Cu}$ and $\mathrm{Zn}$ in suspended sediments from urban. In that work, $\mathrm{Cd}$ ranged from 0.4 to $1.0 \mathrm{mg} \mathrm{kg}^{-1}$ and $\mathrm{Pb}$ varied from 20 to $100 \mathrm{mg} \mathrm{kg}^{-1}$, probably associated to industrial activity, whilst $\mathrm{Cu}\left(30-400 \mathrm{mg} \mathrm{kg}^{-1}\right)$ and $\mathrm{Zn}\left(100-1,500 \mathrm{mg} \mathrm{kg}^{-1}\right)$ are associated to waterproofing of soil and residential areas. The values found by Kuusisto-Hjort and Hjort (2013) for these four metals presented much more variability then those results found for Barigui River suspended sediments (Table 5). The literature considers and assumes threshold values that cause effect on biota is minimum. The proposed values with minimum effects are $0.99 \mathrm{mg} \mathrm{kg}^{-1}$ for $\mathrm{Cd}, 43.4 \mathrm{mg} \mathrm{kg}^{-1}$ for $\mathrm{Cr}, 22.7 \mathrm{mg} \mathrm{kg}^{-1}$ for $\mathrm{Zn}$ and $121.0 \mathrm{mg} \mathrm{kg}^{-1}$ for Zn (MACDONALD; INGERSOLL; BERGER, 2000). These metals examined in Barigui River were in higher concentration than values proposed above.

Considering the values found in natural soil constitution (reference values) of First Plateau of Paraná State and spatial geochemistry distribution of metal in entire Parana State (MINEROPAR, 2005), it can be concluded that metals Cd, Cr, $\mathrm{Ni}, \mathrm{P}, \mathrm{Y}$ and $\mathrm{Zn}$ exceeded the reference values and probably this enrichment process is associated to the urban land use. Whilst $\mathrm{Co}, \mathrm{Sc}$ and Sn presented a minimum enrichment process, however the concentration is still higher and might be result from land use and urbanization.

The high concentration of $\mathrm{Ba}, \mathrm{La}, \mathrm{Na}, \mathrm{Pb}$ and $\mathrm{Sr}$ did not represents a enrichment process, assuming the natural concentration of these metals in Parana soil, thus is not possible to conclude the source, if total natural or anthropic. Aluminum seems have not correlation with urbanization, even showed a positive variability in all sites. The concentration exceeded the reference values in the same way of $\mathrm{Fe}$. In fact $\mathrm{Nb}$, Th and Ti followed the same behavior.

In contrast, $\mathrm{As}, \mathrm{Ca}, \mathrm{K}$ and $\mathrm{Mg}$ presented a decreased in concentration, when the sites experiment high level of urbanization. Although, those metal have a natural occurrence in soil for this area, sometimes higher than the mean values in Parana State. It known that the behavior of these metals are associated with natural composition of soil. Due the low concentration of $\mathrm{V}$ and $\mathrm{Zr}$, it is difficult to associate them with urbanization process. A different scenario was found for $\mathrm{Cu}$ and $\mathrm{Mn}$, which exceeded the reference concentration, thus, the enrichment could be associated to urbanization process.

\section{CONCLUSIONS}

In this study was examined the spatial variation of metals and phosphorus in suspended sediments in order to assess the influence of urbanization on river. Of 27 metals examined, 19 presented positive variation according the urbanization level. The highest variation was found to P, La, Cd, Cr, Na, Ni, Y, Th and $\mathrm{Zn}$.

Definitely Cd, Cr, Ni, P, Y and Zn have association with urbanization and land use. Yet, $\mathrm{Ba}, \mathrm{La}, \mathrm{Na}, \mathrm{Pb}$ and $\mathrm{Sr}$ are inconclusive regarding to urbanization. The elements $\mathrm{Al}, \mathrm{Fe}, \mathrm{Nb}$, Th, Ti, As, $\mathrm{Ca}, \mathrm{K}, \mathrm{Mg}$, Va and $\mathrm{Zr}$ are not associated with urban occupation, being $\mathrm{As}$, $\mathrm{Ca}, \mathrm{K}$ and $\mathrm{Mg}$ strongly associated with soil composition.

\section{ACKNOWLEDGEMENTS}

To Dr. Otavio Licth from Parana State Geological Servey - Mineropar and Brazilian Geological Servey - CPRM to help in discussion and for disponibilization of soil geochemical composition reports. 


\section{REFERENCES}

BRASIL. Conselho Nacional do Meio Ambiente - CONAMA. Resolução n ${ }^{\circ} 454$, de 1 de novembro de 2012. Estabelece as diretrizes gerais e os procedimentos referenciais para o gerenciamento do material a ser dragado em águas sob jurisdição nacional. Diário Oficial da União, Brasília, DF, 8 nov., 2012.

BURTON JUNIOR, G. A. Sediment quality criteria in use around the world. Limnology, v. 3, n. 2, p. 65-76, 2002. http://dx.doi. org/10.1007/s102010200008.

CARTER, J.; OWENS, P. N.; WALLING, D. E.; LEEKS, G. J. L. Fingerprinting suspended sediment sources in a large urban river system. The Science of the Total Environment, v. 314-316, p. 513-534, 2003. PMid:14499548. http://dx.doi.org/10.1016/ S0048-9697(03)00071-8.

CHELLA, M. R.; FERNANDES, C. V. S.; FERMIANO, G. A. Avaliação do Transporte de Sedimentos no Rio Barigui. Revista Brasileira de Recursos Hídricos, v. 10, n. 3, p. 105-111, 2005. http:// dx.doi.org/10.21168/rbrh.v10n3.p105-111.

DAVIS, C. M.; FOX, J. F. Sediment fingerprinting: review of the method and future improvements for allocating nonpoint source pollution. Journal of Environmental Engineering, v. 135, n. 7, p. 490-504, 2009. http://dx.doi.org/10.1061/(ASCE)07339372(2009)135:7(490).

FOX, J. F. Identification of sediment sources in forested watersheds with surface coal mining disturbance using carbon and nitrogen isotopes. Journal of the American Water Resources Association, v. 45, n. 5, p. 1273-1289, 2009. http://dx.doi.org/10.1111/j.17521688.2009.00365.x.

FOX, J. F; MARTIN, D. K. Sediment fingerprinting for calibrating a soil erosion and sediment-yield model in mixed land-use watersheds. Journal of Hydrologic Engineering, v. 20, n. 6, p. 1-11, 2014.

FOX, J. F; PAPANICOLAOU, A. N. The use of carbon and nitrogen isotopes to study watershed erosion processes. Journal of the American Water Resources Association, v. 43, n. 4, p. 1047-1064, 2007. http://dx.doi.org/10.1111/j.1752-1688.2007.00087.x.

FRANZ, C.; MAKESCHIN, F.; WEISS, H.; LORZ, C. Sediments in urban river basins: Identification of sediment sources within the Lago Paranoá catchment, Brasilia DF, Brazil-using the fingerprint approach. The Science of the Total Environment, v. 466-467, p. 513-523, 2014. PMid:23933453. http://dx.doi.org/10.1016/j. scitotenv.2013.07.056.

GALLO, E. L.; BROOKS, P. D.; LOHSE, K. A.; MCLAIN, J. E. T. Land cover controls on summer discharge and runoff solution chemistry of semi-arid urban catchments. Journal of Hydrology, v. 485, p. 37-53, 2013. http://dx.doi.org/10.1016/j.jhydrol.2012.11.054.

GOMES, J. P. O.; NASCIMENTO, E. L.; BASTOS, W. R.; BERNARDI, J. V. E.; LACERDA, L. D. Geoquímica de elementos- traço em sólidos em suspensão no Alto Rio Madeira, Rondônia, Brasil. Geochimica Brasiliensis, v. 23, n. 1, p. 49-66, 2009.

GRUSZOWSKI, K. E.; FOSTER, I. D. L.; LEES, J. A.; CHARLESWORTH, S. M. Sediment sources and transport pathways in a rural catchment, Herefordshire, UK. Hydrological Processes, v. 17, n. 13, p. 2665-2681, 2003. http://dx.doi.org/10.1002/hyp.1296.

HOROWITZ, A. J.; ELRICK, K. A.; SMITH, J. J. Monitoring urban impacts on suspended sediment, trace element, and nutrient fluxes within the City of Atlanta, Georgia, USA: program design, methodological considerations, and initial results. Hydrological Processes, v. 22, n. 10, p. 1473-1496, 2008. http://dx.doi.org/10.1002/hyp.6699.

IAPAR - INSTITUTO AGRONÔMICO DO PARANÁ. Londrina, 2013. Available from: <http://www.iapar.br/modules/conteudo/ conteudo.php?conteudo=595>. Access on: may 2013.

IPARDES-INSTITUTOPARANAENSEDEDESENVOLVIMENTO ECONÔMICO E SOCIAL. Caderno Estatístico Município de Almirante Tamandaré. Santa Cândida, 2016. Available from: <http:/ / www.ipardes. gov.br $/$ cadernos $/$ MontaCadPdf1.php? Municipio $=83500 \& b t O k=0 k>$. Access on: feb. 2016.

IPPUC - INSTITUTO DE PESQUISA E PLANEJAMENTO URBANO DE CURITIBA. Curitiba, 2012. Available from: $<$ http:/ / www.ippuc.org.br/mostrarPagina.php?pagina $=131>$. Access on: feb. 2016.

KUUSISTO-HJORT, P.; HJORT, J. Land use impacts on trace metal concentrations of suburban stream sediments in the Helsinki region, Finland. The Science of the Total Environment, v. 456-457, p. 222-230, 2013. PMid:23602975. http://dx.doi.org/10.1016/j. scitotenv.2013.03.086.

MACDONALD, D. D.; INGERSOLL, C. G.; BERGER, T. A. Development and evaluation of consensus-based sediment quality guidelines for freshwater ecosystems. Archives of Environmental Contamination and Toxicology, v. 39, n. 1, p. 20-31, 2000. PMid:10790498. http://dx.doi.org/10.1007/s002440010075.

MCDONALD, D. M.; LAMOUREUX, S. F.; WARBURTON, J. Assessment of a time-integrated fluvial suspended sediment sampler in a high arctic setting. Geografiska Annaler, v. 92, n. 2, p. 225-235, 2010. http://dx.doi.org/10.1111/j.1468-0459.2010.00391.x.

MCKEE, L. J.; GILBREATH, A. N. Concentrations and loads of suspended sediment and trace element pollutants in a small semiarid urban tributary, San Francisco Bay, California. Environmental Monitoring and Assessment, v. 187, n. 8, p. 499, 2015. PMid:26160738. http://dx.doi.org/10.1007/s10661-015-4710-4.

MIGUEL, D. E.; CHARLESWORTH, E.; ORDÓNEZ, S.; SEIJAS, A.; GEOCHEMICAL, E. Fingerprints and controls in the sediments of an urban river: River Manzanares, Madrid (Spain). The Science of the Total Environment, v. 340, n. 1-3, p. 137-148, 2005. PMid:15752498. http://dx.doi.org/10.1016/j.scitotenv.2004.07.031. 
MINEROPAR - MINERAIS DO PARANÁ, S. A. Atlas geoquímico da Folba Curitiba. Curitiba, 2001.

MINEROPAR - MINERAIS DO PARANÁ, S. A. Levantamento geoquímico multielementar do Estado do Paraná. Curitiba, 2005. v. 2.

PHILliPS, J. M.; RUSSELL, M. A.; WALLING, D. E. Timeintegrated sampling of fluvial suspended sediment: a simple methodology for small catchments. Hydrological Processes, v. 14, n. 14, p. 2589-2602, 2000. http://dx.doi.org/10.1002/10991085(20001015)14:14<2589::AID-HYP94>3.0.CO;2-D.

POLETO, C.; BORTOLUZZI, E. C.; CHARLESWORTH, S. M.; MERTEN, G. H. Urban sediment particle size and pollutants in Southern Brazil. Journal of Soils and Sediments, v. 9, n. 4, p. 317-327, 2009. http://dx.doi.org/10.1007/s11368-009-0102-0.

POLETO, C.; MERTEN, G. H.; MINELLA, J. P. The identification of sediment sources in a small urban watershed in southern Brazil: an application of sediment fingerprinting. Environmental Technology, v. 30, n. 11, p. 1145-1153, 2009. PMid:19947145. http://dx.doi. org/10.1080/09593330903112154.

RIVARO, P.; ÇULLAJ, A.; FRACHE, R.; LAGOMARSINO, C.; MASSOLO, S.; MATTIA, M. C.; UNGARO, N. Heavy metals distribution in suspended particulate matter and sediment collected from Vlora Bay (Albania): a methodological approach for metal pollution evaluation. Journal of Coastal Research, v. 58, p. 54-66, 2011. http://dx.doi.org/10.2112/SI_58_6.

SILVA, E. P.; SIQUEIRA, E. Q.; LEANDRO, W. M. Metais tóxicos em sedimentos urbanos de superfícies asfálticas. Revista Brasileira de Recursos Hidricos, v. 20, n. 1, p. 226-236, 2015. http:/ / dx.doi.org/10.21168/rbrh.v20n1.p226-236.

SUDERHSA - SUPERINTENDÊNCIA DE DESENVOLVIMENTO DE RECURSOS HÍDRICOS E SANEAMENTO AMBIENTAL. Curitiba, 2000. Available from: <http:/ /www.aguasparana.pr.gov. $\mathrm{br} /$ modules $/$ conteudo/conteudo.php? conteudo $=79>$. Access on: feb. 2016.
TAYLOR, K. G.; OWENS, P. N. Sediments in urban river basins: a review of sediment-contaminant dynamics in an environmental system conditioned by human activities. Journal of Soils and Sediments, v. 9, n. 4, p. 281-303, 2009. http://dx.doi.org/10.1007/s11368009-0103-z.

VALTANEN, M.; SILLANPAA, N.; SETALA, H. The effects of urbanization on runoff pollutant concentrations, loadings and their seasonal patterns under cold climate. Water, Air, and Soil Pollution, v. 225, n. 6, p. 1-16, 2014. http://dx.doi.org/10.1007/ s11270-014-1977-y.

WALLING, D. E.; COLLINS, A. L.; JONES, P. A.; LEEKS, G. J. L.; OLD, G. Establishing fine-grained sediment budgets for the Pang and Lambourn LOCAR catchments, UK. Journal of Hydrology, v. 330, n. 1-2, p. 126-141, 2006. http://dx.doi.org/10.1016/j. jhydrol.2006.04.015.

ZGHEIB, S.; MOILLERON, R.; CHEBBO, G. Influence of the land use pattern on the concentrations and fluxes of priority pollutants in urban stormwater. Water Science and Technology, v. 64, n. 7, p. 1450-1458, 2011. PMid:22179642. http://dx.doi. org/10.2166/wst.2011.770.

\section{Authors contributions}

Daniel Macedo Neto: Sample collection, data organization, application of methodology, laboratory activities, interpretation of results and final text.

Sandro Froehner: Discussion of results and collaboration in writing and final review.

Juan Sanez: Discussion of results, laboratory activities and collaboration in writing and final review. 